\title{
Effect of Addition Watermelon Rind Powder on Quality Criteria and Microbial Aspects of Beef Burger Patties during Frozen Storage Periods \\ Badr, S. A. ${ }^{1}$ M. A. El-Waseif ${ }^{1}$ and M. S. Ghaly ${ }^{2}$ \\ ${ }^{1}$ Food Science and Technology Department, Faculty of Agriculture, Al-Azhar University, Cairo, Egypt. \\ ${ }^{2}$ Biochemistry Department, Faculty of Agriculture, Al-Azhar University, Cairo, Egypt. \\ Corresponding Author: Badr, S.A., Food Science and Technology Department, Faculty of \\ Agriculture, Al-Azhar University, Cairo, Egypt. E-mail: badrsaed68@Azhar.edu.eg
}

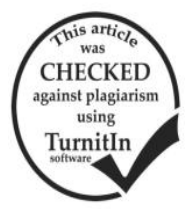

ABESTRACT

The Watermelon rind powder (WMRP) as a natural source of fiber, minerals, amino acids and natural antioxidant compounds. This research was performed to evaluate the influence of addition of WMRP at different level $(3,6,9$ and 12\%) from total formula of beef burger patties on chemical, physiochemical, microbiological and sensory characteristics of beef burger patties during frozen storage period at $-18 \pm 2^{\circ} \mathrm{C}$ up to 90 days. The obtained results showed that the percentage of the WMR about $37.84 \%$ from the total weight of watermelon fruit which can be considered as by-product for processing. However, the WMRP contained crude fiber (15.98\%), total ash (12.55\%), Na (515.44 mg/100g), Ca (311.22 mg/100g), Mg (298.61mg/100g), P (288.28 mg/100g), and K (130.04 mg/100g), while Fe $(12.98 \mathrm{mg} / 100 \mathrm{~g})$ and $\mathrm{Zn}(3.12 \mathrm{mg} / 100 \mathrm{~g})$ as macro and micro elements. Lysine, leucine, valine and isoleucine were the major essential amino acids (4.97, 4.71, 3.75 and $3.14 \mathrm{gm} / 100 \mathrm{gm}$ protein, respectively). Meanwhile, glutamic, arginine, Aspartic, Alanine and Glycine were the major non-essential amino acids $(9.94,8.91,6.63,6.11$ and $5.76 \mathrm{gm} / 100 \mathrm{gm}$ protein, respectively). Moreover, the incorporation of WMRP into the beef burger patties as texturized soy substitute, caused to improvement of gross chemical composition as that increased both of fiber, total ash, total soluble carbohydrates content and decreased crude fat of beef burger patties, as well as the improvement of physiochemical quality criteria ( $\mathrm{pH}$ value, WHC, shrinkage, TVN and TBA values) throughout frozen storage in comparison with control sample. In addition, WMRP inhibited the growth and activity of microbial, as well as reduction of lipid oxidation in tested prepared product. Also, beef burger patties containing the WMRP exhibited a good sensory properties and better acceptability, especially those contained 6 and $9 \%$ WMRP, even after stored for 90 days under frozen condition. The present results are useful of used WMRP in fortification of meat products to improve the nutritionally and healthy safe.

Keywords: Watermelon Rind Powder, Beef burger, Storage Conditions, Quality Criteria.

\section{INTRODUCTION}

Beef burger patties are considered one of the among popular food items which were played a significant role in the modern nutritious diet, as a core member of ready-to-eat family prepared in restaurants and at home (Özkan et al., 2004). Beef burger patties are excellent sources of protein, minerals and vitamins however, ground beef was significant a high of fat than beef sirloin, additionally beef burger patties were a molded mixture of ground lean and fatty beef prepared with added salt and seasoning.

In order to attend economic or technological methods, soy protein is the among widely used vegetables protein as an additive in meat products, due to its high biological value as well as it's a good functional character which result an increased the water holding capacity and improving the texture and the acceptance of the final products (Passos-Maria and kuaye, 2002).

Antioxidants are widely used as additives in meat processed because they were increased the storage stability. There is a large amount of literature on the effects of antioxidants on lipid oxidation processes, whereas literature on the effect on the N-nitrosamines formation in meat products was limited (Li et al., 2013). The present of antioxidant in meat products play the importance role in the kinetic aspects of the nitrite reactions. These antoxidants may reduce the nitrous acid formed from nitrite ion (Skibsted, 2011). Thus, the production of $\mathrm{N}$ nitrosamines may be limited by the presence of ascorbate because it's additives to the several reactions that $\mathrm{NO}$ from nitrite can participate (Hill et al., 1988 and Bryan, 2016).

Watermelon is an important crop grown in the warmer regions of the world. Half of a watermelon fruit is edible while the other half, consisting of about more 35\% rind and $15 \%$ peel goes to waste (USDA, 2004).
Watermelon is one of the most vegetable crops consumed all over the Mediterranean basin. It's much appreciated as an excellent refreshing summer fruits. Besides vitamins (A, B, C and E), minerals ( $\mathrm{K}, \mathrm{Mg}, \mathrm{Ca}$ and $\mathrm{Fe}$ ), amino acids (citrulline converts to arginine), and natural antioxidant compounds such as carotenoids, phenolics, lycopene, ascorbic acid. (Perkins- Veazie et al., 2007).

The citrulline in watermelon rind (WMR) was give it antioxidant effects that protect you from free-radical damage and additionally, citrulline converts to arginine, an amino acid vital to the heart, circulatory system and immune system and also, the WMR might relax blood vessels as cancer and cardiovascular diseases. The rind was usually discarded; they were edible, and sometimes used as a vegetable and were utilized for the products such as preserve, pectin and other products. (Rimando and PerkinsVeazie, 2005).

The aim of the present study was carried out to investigation the effect of addition of watermelon rind powder (WMRP) at different levels (3, 6, 9 and 12\%) from total formula of beef burger patties on chemical, physiochemical, microbiological and sensory characteristics of beef burger patties during frozen storage period at -18 $\pm 2^{\circ} \mathrm{C}$ up to 90 days.

\section{MATERIALS AND METHODS}

\section{Materials:}

Watermelon Fruits (Citrullus lanatus): was obtained from local market in Cairo, Egypt. Waste materials used were obtained manually as watermelon rinds (WMR).

Beef meat: was obtained from local butcher shop in the day before processing of beef burger treatments. 


\section{Texturized soy:}

It was obtained from Food Technology Research Institute, Agricultural Research Center, Giza, Egypt.

Spices: Spices mixture containing of (Cumin 55.0\% Coriander $21.0 \%$ - Black pepper $6.0 \%$ - Cloves $6.0 \%$ Cubeb 3.0\% - Nutmeg 3.0\% - Cardamon 3.0\% - Red pepper $2.0 \%$ and Thyme $1.0 \%$ ) was obtained from Harraz market, Cairo, Egypt.

Another ingredients: Fresh eggs, onion and salt (sodium chloride) were obtained from local market at Nasr City, Cairo, Egypt. While, sodium tripolyphosphate, sodium ascorbate and sodium nitrite were purchased from ElGamhouria Company for Trading Chemicals and Drugs, Cairo, Egypt.

Technological Methods:

Preparation of watermelon rind powder (WMRP):

The watermelon rind was separated from the washed fresh watermelon fruits and cut into small pieces and spreaded on trays of air dryer and dried at $50 \pm 5^{\circ} \mathrm{C}$ for $12 \mathrm{hr}$., then the dehydrated pieces were milled in a laboratory disc mill (Braun AG Frankfurt Type: KM 32, Germany) to fine powder according to the method described by El-Badry et al., (2014).

Preparation of beef burger patties:

Ground beef preparation:

Ground beef was prepared by using sanitized utensils and equipments. The meat was ground in meat grinder (Italmans, Motore Asincrono monoface, Italy) through $6 \mathrm{~mm}$ grinder plate at ambient temperature about $25^{\circ} \mathrm{C}$ (Oroszvári et al., 2005).

Preparation of texturized soy and watermelon rind powder blends:

Watermelon rind powder (WMRP) was replaced individually by $(20,40,60$ and $80 \%)$ of texturized soy, which represented $(3,6,9$ and $12 \%)$ from total formula of beef burger patties. The texturized soy - watermelon rind powder blends were individually blended and homogenized, then kept in polyethylene bags at $\left(4 \pm 1^{\circ} \mathrm{C}\right)$ in a refrigerator for the further processing (Table 1).

Beef burger preparation:

The texturized soy with or without WMRP were hydrated by adequate portion of water; another portion of water was used to dissolve salt and other additives. Ground beef hydrated texturized soy with or without WMRP, salt and another ingredients (Table 1) were mixed by mixer (Braun AG, No, 4122, Germany) for $5 \mathrm{~min}$. to ensure good distribution. After mixing each batch, about $3 \mathrm{~kg}$, used individually in making beef burger patties, $80 \mathrm{~g}$ weight, 1.0 $\mathrm{cm}$ thickness and $10.0 \mathrm{~cm}$ diameter for each. The beef burger patties were aerobically packaged in a foam plates, wrapped with polyethylene film and kept at $-18 \pm 2^{\circ} \mathrm{C}$ until further cooking and analysis every month periodically (Dreeling et al., 2000)

Table 1. Amount and percentage of ingredients used in processing of beef burger patties at different replacement levels.

\begin{tabular}{|c|c|c|c|c|c|}
\hline \multirow{2}{*}{$\begin{array}{l}\text { Ingredients } \\
\text { (g) }\end{array}$} & \multicolumn{5}{|c|}{ Amount and percentage of ingredients at deferent replacement levels } \\
\hline & $\begin{array}{c}\text { Control } \\
\mathrm{g}\end{array}$ & $\begin{array}{c}\text { 3\% WMRP } \\
\mathrm{g}\end{array}$ & $\begin{array}{c}\text { 6\% WMRP } \\
\text { G }\end{array}$ & $\begin{array}{c}\text { 9\% WMRP } \\
\text { g }\end{array}$ & $\begin{array}{c}12 \% \text { WMRP } \\
\mathrm{g}\end{array}$ \\
\hline Ground beef meat & 60 & 60 & 60 & 60 & 60 \\
\hline Texturized soy & 15 & 12 & 9 & 6 & 3 \\
\hline Watermelon rind powder & - & 3 & 6 & 9 & 12 \\
\hline Fresh eggs & 6 & 6 & 6 & 6 & 6 \\
\hline Fresh onion paste & 5.16 & 5.16 & 5.16 & 5.16 & 5.16 \\
\hline Salt (sodium chloride) & 1.5 & 1.5 & 1.5 & 1.5 & 1.5 \\
\hline Iced water & 10.0 & 10.0 & 10.0 & 10.0 & 10.0 \\
\hline Spices mixture & 2.0 & 2.0 & 2.0 & 2.0 & 2.0 \\
\hline S. tripolyphosphate & 0.30 & 0.30 & 0.30 & 0.30 & 0.30 \\
\hline S. ascorbate & 0.03 & 0.03 & 0.03 & 0.03 & 0.03 \\
\hline S. nitrite & 0.015 & 0.015 & 0.015 & 0.015 & 0.015 \\
\hline Total Ingredients* & 100 & 100 & 100 & 100 & 100 \\
\hline
\end{tabular}

Cooking of beef burger patties:

The beef burger patties were cooked for measuring the diameter shrinkage and organoleptic evaluation for them. Burgers were pan-fried on a laboratory grill (Suteskv, Russia), the size of the flat was $300 \times 300 \mathrm{~mm}$, and a pan temperature of $160 \pm 5^{\circ} \mathrm{C}$ was used. Burgers were cooked for $6 \mathrm{~min}$ for each side, as described by (Ou and Mittal, 2006).

Chemical and Physiochemical analysis:

Analytical methods for prepared beef burger patties were carried out initially and periodically at 30 days intervals throughout frozen storage (at- $18 \pm 2{ }^{\circ} \mathrm{C}$ ) for 90 days as follows:

1-Chemical analysis:

Moisture, crude protein (Nx6.25), ether extract, total ash, and crude fiber contents of WMRP and beef burger patties were determined using the methods described of the A.O.A.C. (2000). \% Total soluble carbohydrates were calculated by differences as followed:

$=100-(\%$ crude protein $+\%$ crude fat $+\%$ ash $+\%$ crude fiber $)$. Energy values:

Energy values were calculated theoretically according to the method described by Paul and Southgate (1979) as follows:

Energy value $=4$ (gm Protein + gm Carbohydrates $)+9($ gm Fat $)$. Minerals:

Calcium, Magnesium, Iron, Zinc and Manganese contents of WMRP were determined according to the method of A.O.A.C. (2000), using Atomic Absorption Spectrophotometer-Perkin Elmer, Model 5000, and Germany. Phosphorus was determined by spectrophotometer using molybdovandate method according to A.O.A.C. (2000), while sodium and potassium contents were determined by Flame Photometer (CORNING 400, serial No. 4889,UK). 
Amino acids profile:

The amino acids profile of WMRP was determined as described by Cosmos and Simon-Sarkadi, (2002) using automatic amino acid analyzer (model: AAA 400). Amino acid score (AAS) was calculated accordance to the FAO/WHO (1973) as follows:

$\mathbf{A A S} \%=\mathrm{mg}$ of Amino acid in $1 \mathrm{~g}$ of tested protein $\times 100$ mg of Amino acid in $1 \mathrm{~g}$ of reference protein

Total polyphenols:

Total polyphenols content was conducted according to the modified Folin- Ciocalteu colorimetric method of Singleton et al. (1999).

Total flavonoids:

Total flavonoids content was analyzed according to the method described by Bahorun et al. (2004).

Total glucosinolates content:

Glucosinolates content was determined as allyl isothyocianate $(\mathrm{mg} / 100 \mathrm{~g}$ dry weight basis) according to the method described by Mukhopadhyay and Bhattacharyya (2006).

DPPH \% free radical scavenging activity: was estimated according to the method of Hatano et al. (1988).

Total volatile basic- nitrogen (TVB-N):

Total volatile basic- nitrogen (TVB-N) content in prepared beef burger patties and caper seeds powder sample was determined by macro-distillation method as described by Pearson (1976).

Thiobarbituric acid (TBA):

Thiobarbituric acid (TBA) values of prepared beef burger patties were estimated by colorimetric method at $538 \mathrm{~nm}$ using digital spectrophotometer Spekol 11 No. 849101 (as mg malonaldehyde / kg sample) according to the method of Pearson (1976).

2-Physiochemical analysis:

PH value: $P H$ value was determined according to the procedure described by Schoeni et al. (1991), using a calibrated pH meter (Beckman model 3550, USA).

The Water holding capacity (WHC): The Water holding capacity for beef burger patties was determined by the filter press method as described by Soloviev (1966). A planimeter (PLACOM Digital planimeter KP- $90 \mathrm{~N}$ ) was used for measured the outer zone areas were formed on the filter paper for all samples.

The diameter shrinkage:

The shrinkage percentage was calculated as described by American meat science association (Oroszvári et al. 2006).

$$
\text { Shrinkage }(\%)=\frac{(a-b)+(c-d)}{a+c} \times 100 .
$$

$a=$ Thickness of un cooked burger $\quad b=$ Thickness of cooked burger $\mathrm{c}=$ Diameter of un cooked burger $\quad \mathrm{d}=$ Diameter of cooked burger 3-Microbiological analysis:

Microbiological status of prepared beef burger patties samples (immediately after formulation) was assessed including total bacterial count using Plate Count Agar, incubation at $35-37{ }^{\circ} \mathrm{C}$ for $24-48$, mold and yeast count using Potato Dextrose Agar, incubation at $20-25{ }^{\circ} \mathrm{C}$ for 2-5 days and psychrophilic bacteria count using Plate Count Agar and incubation at 5-7 ${ }^{\circ} \mathrm{C}$ for 5-7 days (Downes and Ito, 2001; Wehr and Frank, 2004; FDA, 2005). while, Coliform bacteria contamination was detected using presumptive test using Mac- Conkey broth and incubation at $35-37^{\circ} \mathrm{C}$ for $24-48 \mathrm{~h}$ (Murray et al., 2007)

\section{4-Sensory evaluation of beef burger patties:}

Beef burger patties containing $(0,3,6,9$ and $12 \%)$ of WMRP as a substitute of SF were subjected to sensory evaluation according to Cross et al. (1978). Sensory evaluation was carried out by 10 panels from educational organization members of Food Science and Technology Department, Faculty of Agriculture, Al-Azhar University. The sensory technique was carried out by using a hedonic test ten-point scale to evaluate color, taste, odor, tenderness, juiciness, appearance and overall acceptability of the tested product samples.

\section{5- Statistical analysis:}

Obtained data were statistically analyzed by using SPSS (version 16.0 software Inc. Chicago, USA) of completely randomized design as described by Gomez and Gomez (1984).

\section{RESULTS AND DISCUSSION}

Average weights of watermelon fruit and percentage of red flesh and whole peel watermelon.

The average weight of watermelon fruit at different sizes (Mean $\pm \mathrm{SE}$ ) for ten watermelon fruits was presented in Table (2). The obtained results clear that the percentage of red flesh of watermelon fruits as the edible portion represented about $56.46 \%$ of the watermelon fruit, while the percentage of rind watermelon about $37.84 \%$ from the total weight as non-edible waste, this rest of the fruit can be considered as a processing by-product (USDA, 2004).

Table 2. The mean average weight of watermelon fruits, the red flesh and whole peel watermelon.

\begin{tabular}{lcccc}
\hline $\begin{array}{l}\text { Size of } \\
\text { watermelon }\end{array}$ & $\begin{array}{c}\text { Total weight of } \\
\text { watermelon Fruit } \\
(\mathbf{g m})\end{array}$ & $\begin{array}{c}\text { Weight of red flesh } \\
\text { watermelon } \\
\mathbf{( g m )}\end{array}$ & $\begin{array}{c}\text { The inner white pulp } \\
\text { of the rind } \\
\text { (gm) }\end{array}$ & $\begin{array}{c}\text { The outer green skin of the } \\
\text { rind } \\
\text { (gm) }\end{array}$ \\
\hline Big size & 8050 & $4705.47 \pm 101.51^{\mathrm{c}}$ & $3020.23 \pm 101.53^{\mathrm{c}}$ & $324.53 \pm 42.20^{\mathrm{c}}$ \\
Minimum size & 3100 & $1590.04 \pm 51.24^{\mathrm{a}}$ & $1197.82 \pm 59.15^{\mathrm{a}}$ & $309.94 \pm 38.90^{\mathrm{a}}$ \\
Means (gm) & 5575 & $3147.75 \pm 79.54$ & $2109.02 \pm 55.30$ & $316.93 \pm 40.32$ \\
Percentage (\%) & 100 & 56.46 & 37.84 & 5.70 \\
\hline
\end{tabular}

Means \pm standard error for the means within the same column having different superscripts are significantly varied $(\mathrm{P} \leq 0.05)$.

Nutritional values of watermelon rind powder (WMRP): Proximate Chemical Composition: The Proximate chemical composition (moisture, crude protein, crude fat, total ash, crude fibers and total soluble carbohydrates) and energy values of WMRP as compared with texturized soy were listed in Table (3).

From the given data it could be showed the significant increase $(\mathrm{P} \leq 0.05)$ in ash, crude fibers and total soluble carbohydrates of WMRP $(12.55,15.98$ and $60.85 \%$, 
respectively) on dry weight as compared with texturized soy $(6.04,4.76$ and $37.23 \%$, respectively).

While, showed a significant decreased $(\mathrm{P} \leq 0.05)$ in crude protein, crude fat and energy values of WMRP $(8.64 \%, 1.98 \%$ and $295.78 \mathrm{Kcal} / \mathrm{g}$, respectively) as compared with texturized soy $(47.28 \%, 4.69 \%$ and 380.25 $\mathrm{Kcal} / \mathrm{g}$, respectively).

Table 3. Chemical composition of watermelon rind powder and texturized soy on dry weight $(\mathrm{M} \pm \mathrm{SE}) * *$.

\begin{tabular}{|c|c|c|}
\hline $\begin{array}{l}\text { Chemical } \\
\text { Composition (\%) }\end{array}$ & $\begin{array}{l}\text { Soy } \\
\text { flour }\end{array}$ & WMRP* \\
\hline Moisture & $7.74 \pm 0.30^{\mathrm{a}}$ & $7.88 \pm 0.38^{\mathrm{a}}$ \\
\hline Protein & $47.28 \pm 0.24^{\mathrm{b}}$ & $8.64 \pm 0.28^{\mathrm{a}}$ \\
\hline Fat & $4.69 \pm 0.13^{b}$ & $1.98 \pm 0.16^{\mathrm{a}}$ \\
\hline Ash $\%$ & $6.04 \pm 0.32^{\mathrm{a}}$ & $12.55 \pm 0.32^{b}$ \\
\hline Fiber $\%$ & $4.76 \pm 0.20^{\mathrm{a}}$ & $15.98 \pm 0.20^{b}$ \\
\hline $\begin{array}{l}\text { total soluble } \\
\text { Carbohydrates \% }\end{array}$ & $37.23 \pm 0.48^{\mathrm{a}}$ & $60.85 \pm 0.52^{b}$ \\
\hline Energy values Kcal/g & $380.25 \pm 0.52^{b}$ & $295.78 \pm 0.48^{\mathrm{a}}$ \\
\hline
\end{tabular}

Thereupon, the watermelon rind powder is considered a good source of crude fiber, total soluble

Table 4. Amino acids composition of watermelon rind FAO/WHO (1973).

\begin{tabular}{|c|c|c|c|c|}
\hline \multicolumn{5}{|c|}{ Watermelon rind powder } \\
\hline Amino acids & $\begin{array}{c}\text { gm/100gm } \\
\text { sample }\end{array}$ & $\begin{array}{c}\text { gm } / 100 g m \\
\text { protein }\end{array}$ & $\begin{array}{l}\text { FAO/WHO(1973) } \\
\text { gm/100g protein }\end{array}$ & Amino acids score (\%) \\
\hline \multicolumn{5}{|c|}{ Essential (indispensable) amino acids (EAA) } \\
\hline Threonine & 0.12 & 1.13 & 4.0 & 28.25 \\
\hline Valine & 0.42 & 3.75 & 5.0 & 75.0 \\
\hline Isoleucine & 0.35 & 3.14 & 4.0 & 78.5 \\
\hline Leucine & 0.53 & 4.71 & 7.0 & 67.28 \\
\hline Phenyl alanine & 0.17 & 1.57 & & \\
\hline Histedine & 0.22 & 2.01 & 6.0 & 59.66 \\
\hline Lysine & 0.56 & 4.97 & 5.5 & 90.36 \\
\hline Total EAA & 2.37 & 21.28 & & \\
\hline \multicolumn{5}{|c|}{ Non- Essential (dispensable) amino acids (NEAA) } \\
\hline Aspartic & 0.75 & 6.63 & & \\
\hline Serine & 0.23 & 2.09 & & \\
\hline Glutamic & 1.13 & 9.94 & & \\
\hline Proline & 0.12 & 1.13 & & \\
\hline Glycine & 0.65 & 5.76 & & \\
\hline Alanine & 0.69 & 6.11 & & \\
\hline Tyrosine & 0.29 & 2.61 & & \\
\hline Arginine & 1.01 & 8.91 & & \\
\hline Total NEAA & 4.87 & 43.09 & & \\
\hline
\end{tabular}

The Minerals content (Na, K, Ca, Mg, P, Fe and $\mathrm{Zn}$ ) of WMRP was determined and listed in Table (5). From the obtained data it could be noticed that, the WMRP contained a high amount of sodium (515.44 $\mathrm{mg} / 100 \mathrm{~g})$, calcium $(311.22 \mathrm{mg} / 100 \mathrm{~g})$, Magnesium (298.61 mg/100g), Phosphorous (288.28 mg/100g), and Potassium (130.04 mg/100g), as macro-elements.

At the same results in Table (5), it could be noticed that the WMRP contained a considerable amount of both Ferrous (12.98mg/100g) and Zinc (3.12 $\mathrm{mg} / 100 \mathrm{~g}$ ) as micro-elements when compared with the reference of minerals pattern (RDA, 1989). The above mentioned results are in accordance with those reported by Perkins Veazie et al., (2007).Generally, the WMRP could be considered as a good source of macro and carbohydrates and minerals. Therefore, it should be utilized in food fortification (Apsara and Pushpalatha, 2002).

The above mentioned data are in accordance with those obtained by Al-Sayed, and Ahmed, (2013).

\section{Nutritional Protein Quality of WMRP:}

The nutritional protein quality of WMRP were evaluated according to its content of essential (indispensable) amino acids, in comparison to the reference protein pattern of FAO/WHO (1973), as presented in Table (4). It could be noticed that, Lysine, Leucine, Valine and Isoleucine were the major essential amino acids of WMRP, it were recorded 4.97, 4.71, 3.75 and 3.14 $\mathrm{gm} / 100 \mathrm{gm}$ protein; respectively. Besides, glutamic, arginine, Aspartic, Alanine and Glycine were the major non- essential (dispensable) amino acids which were found (9.94, 8.91, 6.63, 6.11 and 5.76, gm/100gm protein respectively. These results were relatively comparable with data recorded by Kim et al., (2009).

Generally, the WMRP protein had adequate contents of lysine, leucine, valine and Isoleucine which were the major indispensable amino acids and glutamic, arginine, aspartic, alanine and glycine were the major dispensable amino acids therefore, the use of WMRP in the beef burger patties manufacture and other foodstuffs may be has added economic value for human nutrition.

powder compared by the reference protein pattern of Table 5. Minerals content of watermelon rind powder on dry weight

\begin{tabular}{lcc}
\hline Minerals & $\begin{array}{c}\text { Minerals content of } \\
\text { WMRP* } \mathbf{~ m g / 1 0 0 g}\end{array}$ & $\begin{array}{c}* * \mathbf{R D A} \\
(\mathbf{m g} / \mathbf{d a y})\end{array}$ \\
\hline $\mathrm{Na}$ & 515.44 & $2000-4000$ \\
$\mathrm{~K}$ & 130.04 & $2000-4000$ \\
$\mathrm{Ca}$ & 311.22 & $800-1200$ \\
$\mathrm{Mg}$ & 298.61 & $280-350$ \\
$\mathrm{P}$ & 288.28 & $800-1200$ \\
$\mathrm{Fe}$ & 12.98 & $10-12$ \\
$\mathrm{Zn}$ & 3.12 & $12-15$
\end{tabular}

WMRP* Watermelon rind powder.

RDA**: Recommended Dietary Allowances of minerals 
Antioxidant properties of watermelon rind powder (WMRP):The health promoting phytochemicals including total polyphenol, total flavonoid and total glucosinolate contents as antioxidant compounds and the total antioxidant activities (TAA) of WMRP were determined and the obtained results were shown in Table (6).

Table 6. Phytochemical and Antioxidant activity of watermelon rind powder and texturized soy on dry weight. $(\mathrm{M} \pm \mathrm{SE})$

\begin{tabular}{|c|c|c|}
\hline Items & $\begin{array}{l}\text { Watermelon } \\
\text { rind powder }\end{array}$ & $\begin{array}{l}\text { Texturized } \\
\text { soy }\end{array}$ \\
\hline $\begin{array}{l}\text { Total polyphenols as gallic } \\
\text { acid (ppm) }\end{array}$ & $2308.1 \pm 2.55^{\mathrm{b}}$ & $1575.6 \pm 2.38^{\mathrm{a}}$ \\
\hline Total flavonoids as rutin(ppm) & $3817.5 \pm 2.55^{\mathrm{b}}$ & $1178.9 \pm 2.38^{\mathrm{a}}$ \\
\hline $\begin{array}{l}\text { Total glucosinolates as allyl } \\
\text { isothiocyanate (ppm) }\end{array}$ & $1831.44 \pm 1.89^{\mathrm{b}}$ & $885.5 \pm 2.38^{\mathrm{a}}$ \\
\hline DPPH activity (\%) & $98.46 \pm 0.52^{\mathrm{b}}$ & $61.46 \pm 0.11^{\mathrm{a}}$ \\
\hline $\begin{array}{l}\text { *Means } \pm \text { standard error for } \\
\text { different superscript are signific } \\
\text { DPPH: 1,1-diphenyl-2-picrylhyd } \\
\text { Trolox: 6-hydroxy-2,5,7,8-tetran }\end{array}$ & $\begin{array}{l}\text { leans within the } \\
\text { ntly varied }(\mathrm{P} \leq 0 \text {. } \\
\text { azyl. } \\
\text { ethyl-2- carboxyli }\end{array}$ & me row having \\
\hline
\end{tabular}

From the obtained data, it could be noticed that the WMRP have a highest content of total polyphenols (2308.1 ppm), total flavonoids $(3817.5 \mathrm{ppm})$ and total glucosinolates (1831.44 ppm) as a compared with texturized soy $(1575.6,1178.9$ and $885.5 \mathrm{ppm}$, respectively), also the \% DPPH free radical scavenging activity was a highest in WMRP (98.46\%) when compared with texturized soy $(61.46 \%)$. These results were relatively comparable with those obtained by Tlili, et al., (2011) and Al-Sayed and Ahmed, (2013). So, the addition of WMRP to beef burger patties causes the increase of shelf-life and improve original quality properties, especially the healthy safe quality, with providing the consumer of food containing the WMRP with the healthy beneficial functions.

Quality characteristics of frozen beef burger (at$18 \pm 2^{\circ} \mathrm{C}$ for 90 days) as affected by different levels effect of watermelon rind powder (WMRP) and frozen storage period.

Gross chemical composition of frozen beef burger patties (at-18 $\pm 2^{\circ} \mathrm{C}$ for 90 days):

The chemical composition of beef burger patties (moisture, crude protein, crude fat, total ash, crude fiber and total soluble carbohydrate) at zero time and through frozen storage period for 90 days at $\left(-18 \pm 2^{\circ} \mathrm{C}\right)$ was presented in Table (7).

Table 7. Chemical composition of beef burger (on dry weight) as affected by Substitution levels of WMRP and frozen storage periods (at $-18 \pm 2^{\circ} \mathrm{C}$ for 90 days)

\begin{tabular}{|c|c|c|c|c|c|}
\hline Properties & & Substitute & Is of the WMR & \pm SE) & \\
\hline Storage period (days) & Control & $3 \%$ & $6 \%$ & $9 \%$ & $12 \%$ \\
\hline Moisture\% & & & & & \\
\hline 0 & $67.82 \pm 1.27^{\mathrm{a}}$ & $67.80 \pm 1.30^{\mathrm{a}}$ & $67.75 \pm 1.31^{\mathrm{a}}$ & $67.71 \pm 1.29^{\mathrm{a}}$ & $67.70 \pm 1.31^{\mathrm{a}}$ \\
\hline 30 & $67.66 \pm 1.21^{\mathrm{a}}$ & $67.69 \pm 1.28^{\mathrm{a}}$ & $67.66 \pm 1.29^{\mathrm{a}}$ & $67.67 \pm 1.26^{\mathrm{a}}$ & $67.63 \pm 1.30^{\mathrm{a}}$ \\
\hline 60 & $67.70 \pm 1.24^{\mathrm{a}}$ & $67.71 \pm 1.29^{\mathrm{a}}$ & $67.69 \pm 1.28^{\mathrm{a}}$ & $67.68 \pm 1.28^{\mathrm{a}}$ & $67.60 \pm 1.29^{\mathrm{a}}$ \\
\hline 90 & $67.63 \pm 1.25^{\mathrm{a}}$ & $67.60 \pm 1.27^{\mathrm{a}}$ & $67.61 \pm 1.29^{\mathrm{a}}$ & $67.60 \pm 1.28^{\mathrm{a}}$ & $67.58 \pm 1.26^{\mathrm{a}}$ \\
\hline Protein \% (on dry weigh & & & & & \\
\hline 0 & $58.19 \pm 1.21^{\mathrm{b}}$ & $56.99 \pm 1.27^{\mathrm{b}}$ & $55.77 \pm 1.27^{\mathrm{ab}}$ & $54.60 \pm 1.11^{\mathrm{a}}$ & $53.39 \pm 1.22^{\mathrm{a}}$ \\
\hline 30 & $58.07 \pm 1.17^{\mathrm{b}}$ & $56.10 \pm 1.22^{\mathrm{b}}$ & $55.03 \pm 1.28^{\mathrm{ab}}$ & $54.08 \pm 1.17^{\mathrm{a}}$ & $53.05 \pm 1.27^{\mathrm{a}}$ \\
\hline 60 & $57.35 \pm 1.11^{\mathrm{b}}$ & $55.41 \pm 1.21^{\mathrm{b}}$ & $54.42 \pm 1.29^{\mathrm{ab}}$ & $53.62 \pm 1.15^{\mathrm{a}}$ & $52.66 \pm 1.25^{\mathrm{a}}$ \\
\hline 90 & $56.32 \pm 1.16^{\mathrm{D}}$ & $54.53 \pm 1.18^{\mathrm{b}}$ & $53.77 \pm 1.26^{\mathrm{ab}}$ & $53.00 \pm 1.19^{a}$ & $52.02 \pm 1.27^{\mathrm{a}}$ \\
\hline Fat \% (on dry weight) & & & & & \\
\hline 0 & $14.03 \pm 0.88^{\mathrm{a}}$ & $13.94 \pm 0.91^{\mathrm{a}}$ & $13.86 \pm 0.97^{\mathrm{a}}$ & $13.76 \pm 0.90^{\mathrm{a}}$ & $13.67 \pm 0.96^{\mathrm{a}}$ \\
\hline 30 & $13.63 \pm 0.87^{\mathrm{a}}$ & $13.21 \pm 0.93^{\mathrm{a}}$ & $13.90 \pm 0.94^{\mathrm{a}}$ & $13.50 \pm 0.92^{\mathrm{a}}$ & $13.00 \pm 0.93^{\mathrm{a}}$ \\
\hline 60 & $12.77 \pm 0.83^{\mathrm{a}}$ & $12.67 \pm 0.97^{\mathrm{a}}$ & $13.03 \pm 0.92^{\mathrm{a}}$ & $12.91 \pm 0.91^{\mathrm{a}}$ & $12.83 \pm 0.92^{\mathrm{a}}$ \\
\hline 90 & $11.95 \pm 0.80^{\mathrm{b}}$ & $12.03 \pm 0.98^{\mathrm{D}}$ & $12.36 \pm 0.91^{\mathrm{ab}}$ & $12.61 \pm 0.97^{\mathrm{ab}}$ & $12.70 \pm 0.97^{\mathrm{a}}$ \\
\hline Ash \% (on dry weight) & & & & & \\
\hline 0 & $10.54 \pm 0.97^{\mathrm{a}}$ & $10.75 \pm 0.87^{\mathrm{a}}$ & $10.94 \pm 0.83^{\mathrm{ab}}$ & $11.17 \pm 0.87^{\mathrm{ab}}$ & $11.34 \pm 0.87^{\mathrm{b}}$ \\
\hline 30 & $10.50 \pm 0.98^{\mathrm{a}}$ & $10.54 \pm 0.88^{\mathrm{a}}$ & $10.59 \pm 0.87^{\mathrm{ab}}$ & $10.61 \pm 0.85^{a b}$ & $10.68 \pm 0.80^{\mathrm{b}}$ \\
\hline 60 & $10.44 \pm 0.94^{\mathrm{a}}$ & $10.50 \pm 0.90^{\mathrm{a}}$ & $10.55 \pm 0.88^{\mathrm{ab}}$ & $10.58 \pm 0.87^{\mathrm{ab}}$ & $10.61 \pm 0.84^{\mathrm{b}}$ \\
\hline 90 & $10.40 \pm 0.93^{\mathrm{a}}$ & $10.43 \pm 0.89^{\mathrm{a}}$ & $10.48 \pm 0.87^{\mathrm{ab}}$ & $10.50 \pm 0.89^{a b}$ & $10.53 \pm 0.89^{b}$ \\
\hline Fiber \% (on dry weight & & & & & \\
\hline 0 & $0.84 \pm 0.09^{\mathrm{a}}$ & $1.16 \pm 0.07^{\mathrm{b}}$ & $1.49 \pm 0.07^{\mathrm{c}}$ & $1.81 \pm 0.07^{\mathrm{d}}$ & $2.13 \pm 0.07^{\mathrm{e}}$ \\
\hline 30 & $0.79 \pm 0.10^{\mathrm{a}}$ & $1.10 \pm 0.07^{\mathrm{b}}$ & $1.43 \pm 0.07^{\mathrm{c}}$ & $1.79 \pm 0.08^{\mathrm{d}}$ & $2.11 \pm 0.08^{\mathrm{e}}$ \\
\hline 60 & $0.75 \pm 0.07^{\mathrm{a}}$ & $1.06 \pm 0.07^{\mathrm{b}}$ & $1.37 \pm 0.07^{\mathrm{c}}$ & $1.75 \pm 0.07^{\mathrm{d}}$ & $2.10 \pm 0.07^{\mathrm{e}}$ \\
\hline 90 & $0.71 \pm 0.08^{\mathrm{a}}$ & $1.01 \pm 0.09^{\mathrm{b}}$ & $1.30 \pm 0.09^{c}$ & $1.70 \pm 0.09^{\mathrm{d}}$ & $2.10 \pm 0.07^{\mathrm{e}}$ \\
\hline total soluble Carbohydr & $\%$ (on dry $\mathrm{w}$ & & & & \\
\hline 0 & $16.4 \pm 0.10^{\mathrm{a}}$ & $17.16 \pm 0.07^{\mathrm{ab}}$ & $17.94 \pm 0.07^{\mathrm{bc}}$ & $18.66 \pm 0.07^{\mathrm{cd}}$ & $19.47 \pm 0.11^{\mathrm{d}}$ \\
\hline 30 & $14.27 \pm 0.11^{\mathrm{a}}$ & $14.66 \pm 0.09^{\mathrm{ab}}$ & $14.80 \pm 0.09^{\mathrm{bc}}$ & $15.60 \pm 0.07^{\mathrm{cd}}$ & $16.25 \pm 0.07^{\mathrm{d}}$ \\
\hline 60 & $14.15 \pm 0.10^{\mathrm{a}}$ & $14.59 \pm 0.07^{\mathrm{ab}}$ & $14.75 \pm 0.11^{\mathrm{bc}}$ & $15.42 \pm 0.11^{\mathrm{cd}}$ & $16.13 \pm 0.11^{\mathrm{a}}$ \\
\hline 90 & $14.03 \pm 0.09^{\mathrm{a}}$ & $14.51 \pm 0.07^{\mathrm{ab}}$ & $14.64 \pm 0.09^{\mathrm{bc}}$ & $15.26 \pm 0.07^{\mathrm{cd}}$ & $16.01 \pm 0.07^{\mathrm{a}}$ \\
\hline
\end{tabular}

Means \pm standard error; the means within the same row having different superscripts are significantly varied $(\mathbf{P} \leq \mathbf{0 . 0 5})$.

Total soluble Carbohydrates\% calculated by deference as following: 100-(Protein+ Fat + Ash + Fiber) 
From statistical analysis of these obtained data in Table (7), it could be noticed that non-significant differences in moisture content in all beef burger patties samples control and containing WMRP at zero time or observed throughout frozen storage period.

Also, showed that a non-significant differences in crude protein content between beef burger patties control and containing (3 and 6\%) WMRP, while caused a significant decrease with beef burger patties control and containing ( 9 and 12\%) WMRP at zero time or observed throughout frozen storage period

In the same way, from obtained results in Table (7), it could be noticed that non- significant differences in crude fat content in all beef burger patties control and samples containing WMRP at zero time and but caused a significant increased between beef burger patties control and samples containing WMRP (12\%) WMRP when the end frozen storage period.

Also, for ash content showed a non- significant difference between sample control and containing (3, 6 and $9 \%$ ) WMRP, while caused a significant increase with beef burger patties containing (12\%) WMRP at zero time or observed throughout frozen storage period

On the other hand, from data in Table (7), it could be appeared that a significant increase in crude fiber content of beef burger patties containing at different levels (3, 6, 9 and 12\%) of WMRP as compared with control sample at zero time also, and through frozen storage period for 90 days at $\left(-18 \pm 2^{\circ} \mathrm{C}\right)$ observed throughout frozen storage period.

In the same way, for total carbohydrates content, showed that a significant increase in total carbohydrates content for sample contained 6, 9 and 12\% WMRP as compared with control sample at zero time and through frozen storage period. But showed non-significant differences with beef burger patties samples contained $3 \%$ WMRP at zero time and through frozen storage period. The above mentioned data are in accordance with those obtained by Al-Sayed, and Ahmed, (2013) and Akgül and Özcan, (1999).

Generally, the WMRP it was considered a good source of crude fiber and minerals and low fat content. Therefore, it could be the beef burger patties containing WMRP had a good nutritional quality even after frozen storage for 90 days at $-18 \pm 2^{\circ} \mathrm{C}$, and the incorporation of the WMRP into the beef burger patties, as a substitute of SF, could be improved their nutritional quality with regards fat, ash and crude fiber contents

Physiochemical quality criteria of frozen beef burger patties (at-18 $\pm 2{ }^{\circ} \mathrm{C}$ for 90 days) as affected by addition different levels of WMRP instead of texturized soy and storage periods:

Frozen storage stability for the most important physiochemical quality criteria of prepared beef burger patties; including the $\mathrm{pH}$ value, water holding capacity (WHC), shrinkage, total volatile basic-nitrogen (TVB-N) content and thiobarbituric acid (TBA) value, as affected by addition levels of WMRP were investigated and presented in Table (8). From the obtained results it could be noticed that, the addition of WMRP, instead of texturized soy to beef burger patties recorded no significant decrease
$(\mathrm{P} \leq 0.05)$ in $\mathrm{pH}$ values when compared with control sample. On the other hand, the $\mathrm{pH}$ value was increased continuously in all beef burger patties throughout frozen storage. The increment rate was slight decreased as the addition level of WMRP increase, whereas, the control sample exhibited the highest $\mathrm{pH}$ value at any time of frozen storage. The increment of $\mathrm{pH}$ values for all tested beef burger throughout frozen storage may be attributed mainly to breakdown and degradation of beef burgers protein during storage resulting in formation of some basic compounds such as volatile basic nitrogen compounds, amines and hydrogen sulfide, leading to increase the $\mathrm{pH}$ value (Stahnke, 1995). From the same data, it could be observed that the WHC of beef burger patties samples were slightly $(\mathrm{P} \leq 0.05)$ increased by increasing the incorporation level of WMRP from $3 \%$ to $12 \%$ into the beef burger patties, as the result of increment crude fiber and carbohydrates, by incorporating the WMRP into the product, which characterized with a highly efficiency to bound water. During frozen storage, the WHC values were decreased continuously in all tested beef burger patties, especially in control sample, with extending the frozen storage period as the result of breakdown the hydrogen bonding between the water molecules and the other components of beef burgers by the effect of freezing process (Oroszvári et al.,2005). Also, the loss of WHC during frozen storage may be due to protein denaturation and loss of protein solubility (Osheba et al., 2013)

With regards diameter shrinkage which was considered one of the most important physiochemical quality changes that occurs in beef burgers during frying process due to the protein denaturation and squeezing out fat and water from beef burger patties. As given in Table (8), the percentage of diameter shrinkage in beef burger patties was decreased continuously with increasing the addition level of WMRP. In addition, the shrinkage increased linearly for all tested beef burger patties during frozen storage, but it was more evident in the control sample than the other samples containing the WMRP at different levels of 3 to $12 \%$. These results are in accordance with those found by Oroszvári et al. (2005). On the other hand, the thiobarbituric acid values (TBA) of beef burger patties were affected by WMRP addition and frozen storage period, as given in Table (8). Also, it could be noticed that the incorporation of WMRP into the beef burger patties caused significant decreased $(\mathrm{P} \leq 0.05)$ in TBA values by increasing substitution level $(3,6,9$ and $12 \%$ of WMRP) $(0.76,0.59,0.54$ and $0.43 \mathrm{mg} / \mathrm{kg}$, respectively) as compared with control sample (0.91 $\mathrm{mg} / \mathrm{kg}$ ) at zero time. TBA values of different beef burger sample were gradually increased with advancement of frozen storage period. This increase in TBA values during storage could be indicating continuous oxidation of lipid and consequently the production of oxidative by products (Brewer et al. 1992 and Osheba et al., 2013). Also, TBA values through frozen storage period for 90 days at (-18 $\left.\pm 2^{\circ} \mathrm{C}\right)$ showed a significant decrement $(\mathrm{P} \leq 0.05)$ for beef burger patties samples contained WMRP as compared with control sample. The above mentioned data are in accordance with those obtained by (Zhang et al., 2005). 
Table 8. Physiochemical properties of beef burgers as affected by Substitution levels of WMRP and frozen storage periods at $-18 \pm 2^{\circ} \mathrm{C}$ for 90 days.

\begin{tabular}{|c|c|c|c|c|c|}
\hline \multirow{3}{*}{$\begin{array}{l}\text { Physiochemical } \\
\text { properties Storage } \\
\text { period (days) }\end{array}$} & \multicolumn{5}{|c|}{ Substitution levels of the WMRP $(\mathrm{M} \pm \mathrm{SE})$} \\
\hline & Control & $3 \%$ & $6 \%$ & $9 \%$ & $12 \%$ \\
\hline & \multicolumn{5}{|c|}{ PH value } \\
\hline Zero time & $6.94 \pm 0.27^{\mathrm{a}}$ & $6.92 \pm 0.29^{\mathrm{a}}$ & $6.88 \pm 0.22^{\mathrm{a}}$ & $6.77 \pm 0.27^{\mathrm{a}}$ & $6.75 \pm 0.25^{\mathrm{a}}$ \\
\hline 30 & $7.01 \pm 0.33^{\mathrm{a}}$ & $7.00 \pm 0.26^{\mathrm{a}}$ & $6.96 \pm 0.25^{\mathrm{a}}$ & $6.86 \pm 0.26^{\mathrm{a}}$ & $6.83 \pm 0.26^{\mathrm{a}}$ \\
\hline 60 & $7.19 \pm 0.29^{\mathrm{a}}$ & $7.16 \pm 0.28^{\mathrm{a}}$ & $7.11 \pm 0.26^{\mathrm{a}}$ & $7.05 \pm 0.28^{\mathrm{a}}$ & $7.02 \pm 0.27^{\mathrm{a}}$ \\
\hline \multirow[t]{2}{*}{90} & $7.30 \pm 0.28^{\mathrm{a}}$ & $7.20 \pm 0.27^{\mathrm{a}}$ & $7.21 \pm 0.29^{\mathrm{a}}$ & $7.23 \pm 0.29^{\mathrm{a}}$ & $7.25 \pm 0.28^{\mathrm{a}}$ \\
\hline & \multicolumn{5}{|c|}{ Water Holding Capacity (WHC) as bound water \% } \\
\hline Zero time & $83.15 \pm 1.18^{\mathrm{a}}$ & $83.32 \pm 1.15^{\mathrm{a}}$ & $83.47 \pm 1.11^{\mathrm{a}}$ & $83.63 \pm 1.10^{\mathrm{a}}$ & $83.78 \pm 1.13^{\mathrm{a}}$ \\
\hline 30 & $82.73 \pm 1.17^{\mathrm{a}}$ & $83.12 \pm 1.16^{\mathrm{a}}$ & $83.31 \pm 1.10^{\mathrm{a}}$ & $83.57 \pm 1.11^{\mathrm{a}}$ & $83.31 \pm 1.10^{\mathrm{a}}$ \\
\hline 60 & $81.94 \pm 1.11^{\mathrm{a}}$ & $82.37 \pm 1.10^{\mathrm{a}}$ & $82.64 \pm 1.09^{\mathrm{a}}$ & $82.97 \pm 1.13^{\mathrm{a}}$ & $83.08 \pm 1.11^{\mathrm{a}}$ \\
\hline \multirow[t]{2}{*}{90} & $80.59 \pm 1.12^{\mathrm{a}}$ & $81.73 \pm 1.11^{\mathrm{a}}$ & $82.13 \pm 1.03^{\mathrm{a}}$ & $82.53 \pm 1.10^{\mathrm{a}}$ & $82.62 \pm 1.12^{\mathrm{a}}$ \\
\hline & \multicolumn{5}{|c|}{ Shrinkage $\%$} \\
\hline Zero time & $9.64 \pm 0.45^{\mathrm{b}}$ & $9.45 \pm 0.44^{\mathrm{ab}}$ & $9.23 \pm 0.43^{\mathrm{ab}}$ & $9.13 \pm 0.45^{\mathrm{a}}$ & $9.02 \pm 0.46^{\mathrm{a}}$ \\
\hline 30 & $10.53 \pm 0.48^{\mathrm{c}}$ & $10.01 \pm 0.49^{\mathrm{b}}$ & $9.98 \pm 0.49^{b}$ & $9.53 \pm 0.47^{\mathrm{ab}}$ & $9.23 \pm 0.49^{\mathrm{a}}$ \\
\hline 60 & $12.14 \pm 0.51^{\mathrm{c}}$ & $10.60 \pm 0.48^{b}$ & $10.13 \pm 0.47^{b}$ & $9.60 \pm 0.49^{\mathrm{ab}}$ & $9.46 \pm 0.44^{\mathrm{a}}$ \\
\hline \multirow[t]{2}{*}{90} & $13.18 \pm 0.59^{\mathrm{d}}$ & $11.01 \pm 0.44^{\mathrm{c}}$ & $10.31 \pm 0.49^{\mathrm{b}}$ & $9.91 \pm 0.48^{\mathrm{ab}}$ & $9.64 \pm 0.48^{\mathrm{a}}$ \\
\hline & \multicolumn{5}{|c|}{ Thiobarbituric acid value (TBA) mg malonaldhyde/kg sample } \\
\hline Zero time & $0.91 \pm 0.10^{\mathrm{e}}$ & $0.76 \pm 0.12^{\mathrm{d}}$ & $0.59 \pm 0.09^{\mathrm{c}}$ & $0.54 \pm 0.07^{\mathrm{b}}$ & $0.43 \pm 0.08^{\mathrm{a}}$ \\
\hline 30 & $1.17 \pm 0.17^{\mathrm{e}}$ & $0.99 \pm 0.16^{\mathrm{d}}$ & $0.71 \pm 0.11^{\mathrm{c}}$ & $0.63 \pm 0.08^{\mathrm{b}}$ & $0.47 \pm 0.09^{\mathrm{a}}$ \\
\hline 60 & $1.54 \pm 0.14^{\mathrm{e}}$ & $1.28 \pm 0.15^{\mathrm{d}}$ & $0.84 \pm 0.12^{\mathrm{c}}$ & $0.76 \pm 0.09^{\mathrm{b}}$ & $0.52 \pm 0.08^{\mathrm{a}}$ \\
\hline 90 & $2.05 \pm 0.19^{\mathrm{e}}$ & $1.84 \pm 0.18^{\mathrm{d}}$ & $1.19 \pm 0.16^{\mathrm{c}}$ & $0.95 \pm 0.11^{\mathrm{b}}$ & $0.76 \pm 0.10^{\mathrm{a}}$ \\
\hline \multicolumn{6}{|c|}{ Total Volatile Nitrogen value (TVN) mg/ 100g sample } \\
\hline 0 & $11.79 \pm 0.37^{\mathrm{b}}$ & $11.12 \pm 0.31^{\mathrm{a}}$ & $10.50 \pm 0.32^{\mathrm{a}}$ & $10.30 \pm 0.29^{\mathrm{a}}$ & $10.13 \pm 0.28^{\mathrm{a}}$ \\
\hline 30 & $17.12 \pm 0.32^{c}$ & $14.53 \pm 0.34^{b}$ & $13.82 \pm 0.31^{b}$ & $13.44 \pm 0.30^{\mathrm{ab}}$ & $13.12 \pm 0.29^{\mathrm{a}}$ \\
\hline 60 & $22.19 \pm 0.34^{\mathrm{e}}$ & $20.69 \pm 0.37^{\mathrm{d}}$ & $19.09 \pm 0.35^{\mathrm{c}}$ & $16.22 \pm 0.37^{b}$ & $15.00 \pm 0.31^{\mathrm{a}}$ \\
\hline 90 & $27.10 \pm 0.35^{\mathrm{e}}$ & $25.83 \pm 0.33^{\mathrm{d}}$ & $23.20 \pm 0.37^{\mathrm{c}}$ & $21.06 \pm 0.35^{b}$ & $20.01 \pm 0.34^{\mathrm{a}}$ \\
\hline
\end{tabular}

$\mathbf{M} \pm$ SE: Means \pm standard error; the means within the same row having different superscripts are significantly varied $(P \leq 0.05)$.

Concerning, as given in Table (8), it could be showed that the incorporation of the WMRP into the beef burger patties caused significant decreased $(\mathrm{P} \leq 0.05)$ in TVN values, as the addition level increase $(3,6,9$ and $12 \%)$ of WMRP it were presented (11.12, 10.50, 10.30 and $10.13 \mathrm{mg} / 100 \mathrm{~g}$, respectively) as compared with control sample $(11.79 \mathrm{mg} / 100 \mathrm{~g})$ at zero time storage, On the other hand, a gradual increase in TVN values of all tested beef burger patties was observed throughout frozen storage up to 90 days, but the control sample represented significant increased $(\mathrm{P} \leq 0.05)$ when compared with beef burger patties containing WMRP at any time of frozen storage.

In general, the addition of WMRP into beef burger patties led to significant decrement for both TBA and TVN values may be due to the antimicrobial and antioxidant properties of WMRP due to its high phytochemical compounds such as polyphenols, flavonoids, glucosinolates content as shown Table (6).

Microbiological aspects of frozen beef burger patties (at-18 $\pm 2{ }^{\circ} \mathrm{C}$ for 90 days) as affected by addition different levels of WMRP instead of texturized soy and frozen storage periods:

In view of safety evaluation of any processed foods to be ready for human consumption, the microbiological quality is mainly undertaken (Lin et al., 2000) and also, Its known that meat and their products are considered one of the most perishable foods therefore, it's of great importance to follow up the microbiological case of the prepared beef burger trials to protect consumers health against microbiological illnesses among food-borne diseases and to achieve the healthy safe quality of the final product for a long storage period (Rhee et al. 2003).

In this study, frozen storage (at $-18 \pm 2^{\circ} \mathrm{C}$ for 90 days) stability for microbiological aspects of beef burger patties samples including; total bacterial count (TBC), mold and yeast counts, Psychrophilic bacteria and coliform bacteria group were examined periodically at 30 days intervals during frozen storage for 90 days. The obtained results are recorded in Table (9). From statistical, it could be noticed that no significant differences $(\mathrm{P} \leq 0.05)$ in microbial counts (TBC, mold and yeast counts, Psychrophilic bacteria and coliform bacterium) between all beef burger patties samples at zero time of frozen storage. After that, the counts of the former microbial were recorded significant increase $(\mathrm{P} \leq 0.05)$ throughout frozen storage up to 90 days, as the result of their adaptation on freezing conditions. On the other hand, the reduction rate in the former microbial count for beef burger patties samples containing WMRP was increased with increasing the addition levels (3, 6, 9 and $12 \%$ of WMRP) and also much higher than control sample, it's the result of the complementary effect of freezing and the antimicrobial effect of polyphenols, flavonoids and glucosinolates content of WMRP and their breakdown products especially allyl isothiocyanate which are naturally occurred at a high concentration in the WMRP (Keum et al., 2004).

It's worth to note that the tested microbial quality criteria of all beef burger were within the permissible counts reported by EOS. (2005), that recommended the total bacterial and coliform bacteria group counts not 
exceed 5 and $3 \log \mathrm{cfu} / \mathrm{g}$; respectively for frozen beef burgers and as free from Staphylococcus aureus.

Generally, it could be seen that the reducing rate of microbial aspects count for beef burger patties samples containing WMRP during frozen storage it could be mainly attributed to the antimicrobial and antioxidant properties of polyphenols, flavonoids, glucosinolates for WMRP, and their breakdown products especially allyl isothiocyanate which are naturally occurred at a high concentration in the WMRP.

Table 9. Microbiological aspects (log cfu/g) of beef burgers as affected by Substitution levels of WMRP and frozen storage period at $-18 \pm 2^{\circ} \mathrm{C}$.

\begin{tabular}{|c|c|c|c|c|c|}
\hline \multirow{3}{*}{$\begin{array}{l}\text { Microbiological } \\
\text { aspects Storage } \\
\text { period (days) }\end{array}$} & \multicolumn{5}{|c|}{ Substitution levels of WMRP $(M \pm S E)$} \\
\hline & Control & $3 \%$ & $6 \%$ & $9 \%$ & $12 \%$ \\
\hline & \multicolumn{5}{|c|}{ Total bacterial count (TBC) } \\
\hline 0 & $4.23 \pm 0.10^{\mathrm{a}}$ & $4.20 \pm 0.11^{\mathrm{a}}$ & $4.20 \pm 0.10^{\mathrm{a}}$ & $4.18 \pm 0.11^{\mathrm{a}}$ & $4.12 \pm 0.10^{\mathrm{a}}$ \\
\hline 30 & $4.39 \pm 0.11^{\mathrm{b}}$ & $4.18 \pm 0.10^{\mathrm{ab}}$ & $4.14 \pm 0.11^{\mathrm{a}}$ & $4.09 \pm 0.10^{\mathrm{a}}$ & $4.07 \pm 0.09^{\mathrm{a}}$ \\
\hline 60 & $4.44 \pm 0.09^{\mathrm{b}}$ & $4.32 \pm 0.11^{\mathrm{ab}}$ & $4.23 \pm 0.09^{\mathrm{a}}$ & $4.19 \pm 0.08^{\mathrm{a}}$ & $4.15 \pm 0.08^{\mathrm{a}}$ \\
\hline \multirow[t]{2}{*}{90} & $4.69 \pm 0.12^{b}$ & $4.47 \pm 0.09^{\mathrm{a}}$ & $4.40 \pm 0.10^{\mathrm{a}}$ & $4.33 \pm 0.09^{\mathrm{a}}$ & $4.29 \pm 0.08^{\mathrm{a}}$ \\
\hline & \multicolumn{5}{|c|}{ Molds \& yeasts } \\
\hline 0 & $3.10 \pm 0.08^{\mathrm{a}}$ & $3.06 \pm 0.07^{\mathrm{a}}$ & $3.04 \pm 0.09^{\mathrm{a}}$ & $3.03 \pm 0.07^{\mathrm{a}}$ & $3.02 \pm 0.09^{\mathrm{a}}$ \\
\hline 30 & $3.05 \pm 0.07^{\mathrm{b}}$ & $2.98 \pm 0.08^{\mathrm{ab}}$ & $2.88 \pm 0.07^{\mathrm{a}}$ & $2.82 \pm 0.08^{\mathrm{a}}$ & $2.80 \pm 0.07^{\mathrm{a}}$ \\
\hline 60 & $3.31 \pm 0.06^{\mathrm{b}}$ & $3.02 \pm 0.06^{\mathrm{ab}}$ & $2.98 \pm 0.08^{\mathrm{ab}}$ & $2.95 \pm 0.07^{\mathrm{a}}$ & $2.92 \pm 0.08^{\mathrm{a}}$ \\
\hline \multirow[t]{2}{*}{90} & $3.65 \pm 0.07^{\mathrm{b}}$ & $3.36 \pm 0.08^{\mathrm{ab}}$ & $3.30 \pm 0.09^{\mathrm{ab}}$ & $3.20 \pm 0.09^{\mathrm{a}}$ & $3.15 \pm 0.09^{\mathrm{a}}$ \\
\hline & \multicolumn{5}{|c|}{ Psychrophilic bacteria } \\
\hline 0 & $2.78 \pm 0.07^{\mathrm{a}}$ & $2.75 \pm 0.08^{\mathrm{a}}$ & $2.74 \pm 0.08^{\mathrm{a}}$ & $2.73 \pm 0.09^{\mathrm{a}}$ & $2.70 \pm 0.08^{\mathrm{a}}$ \\
\hline 30 & $3.19 \pm 0.08^{b}$ & $3.14 \pm 0.07^{\mathrm{b}}$ & $2.94 \pm 0.07^{\mathrm{a}}$ & $2.86 \pm 0.07^{\mathrm{a}}$ & $2.82 \pm 0.09^{\mathrm{a}}$ \\
\hline 60 & $3.34 \pm 0.09^{\mathrm{b}}$ & $3.29 \pm 0.08^{\mathrm{b}}$ & $3.10 \pm 0.08^{\mathrm{a}}$ & $3.08 \pm 0.08^{\mathrm{a}}$ & $3.06 \pm 0.07^{\mathrm{a}}$ \\
\hline \multirow[t]{2}{*}{90} & $3.43 \pm 0.08^{\mathrm{b}}$ & $3.36 \pm 0.07^{\mathrm{b}}$ & $3.19 \pm 0.07^{\mathrm{a}}$ & $3.11 \pm 0.07^{\mathrm{a}}$ & $3.08 \pm 0.08^{\mathrm{a}}$ \\
\hline & \multicolumn{5}{|c|}{ Coliform group } \\
\hline 0 & $2.20 \pm 0.07^{\mathrm{a}}$ & $2.15 \pm 0.07^{\mathrm{a}}$ & $2.13 \pm 0.07^{\mathrm{a}}$ & $2.13 \pm 0.07^{\mathrm{a}}$ & $2.11 \pm 0.08^{\mathrm{a}}$ \\
\hline 30 & $2.41 \pm 0.09^{c}$ & $2.14 \pm 0.07^{\mathrm{b}}$ & $2.09 \pm 0.08^{\mathrm{b}}$ & $1.88 \pm 0.08^{\mathrm{a}}$ & $1.85 \pm 0.07^{\mathrm{a}}$ \\
\hline 60 & $2.48 \pm 0.07^{\mathrm{c}}$ & $2.09 \pm 0.09^{\mathrm{b}}$ & $1.96 \pm 0.07^{\mathrm{ab}}$ & $1.89 \pm 0.09^{\mathrm{a}}$ & $1.87 \pm 0.08^{\mathrm{a}}$ \\
\hline 90 & $2.55 \pm 0.09^{c}$ & $2.11 \pm 0.07^{\mathrm{b}}$ & $2.04 \pm 0.09^{\mathrm{ab}}$ & $1.93 \pm 0.07^{\mathrm{a}}$ & $1.89 \pm 0.09^{\mathrm{a}}$ \\
\hline
\end{tabular}

$\mathbf{M} \pm$ SE: Means \pm standard error; the means within the same row having different superscripts are significantly varied $(\mathrm{P} \leq 0.05)$.

Organoleptic quality criteria of frozen beef burger patties (at-18 $\pm 2^{\circ} \mathrm{C}$ ) as affected by addition different levels of WMRP instead of texturized soy and frozen storage periods:

The organoleptic properties of meat products were greatly affected by the ingredients used in processing treatments and by storage conditions. They also correlated significantly with physiochemical, chemical and microbiological quality criteria of these products. Sensory evaluation, together with estimation the former criteria have been used extensively to assess the quality of meat products. Therefore, the organoleptic evaluation was carried out in order to evaluate the color, taste, odor, tenderness, juiciness, appearance and overall acceptability of beef burger treatments as affected by addition of WMRP at different levels of $(3,6,9$ and $12 \%)$ instead of texturized soy during frozen storage at $-18 \pm 2{ }^{\circ} \mathrm{C}$ up to 90 days compared with the control samples. The obtained data are statistically analyzed and recorded in Table (10).

As show in Table (10), it could be noticed that there was no significant $(\mathrm{P} \leq 0.05)$ alteration in all sensory quality criteria between beef burger sample containing WMRP up to the level of $9 \%$ and control beef burger sample. While, the increment of incorporation level to $12 \%$ into the product caused a significant decreased all sensory properties of beef burger patties when compared with the control sample. Beef burger patties containing 9\% WMRP had the highest sensory scores for tenderness, juiciness, appearance and overall acceptability, and also there was no significant variation $(\mathrm{P} \leq 0.05)$ between it and other characteristics judging scores and the corresponding scores for the control sample. On the other hand, there was a negligible alteration in the sensory evaluation scores for the tested organoleptic properties of control sample and beef burger patties containing WMRP up to the addition level of $9 \%$, after which no significant variation in the most properties was occurred throughout frozen storage, when compared to control sample. While, the beef burger patties containing WMRP up to the level of $12 \%$ showed a significant decrease in the tested organoleptic quality properties of beef burger patties when compared with the control sample especially at the end of frozen storage period. The above mentioned data are in accordance with those obtained by Abd-Elghany (2014)

In general, it could be showed that beef burger patties containing the WMRP exhibited a good sensory properties and better acceptability when compared with control sample, especially with incorporation of $9 \%$ WMRP, even after stored for 90 days under frozen storage conditions (at $-18 \pm 2{ }^{\circ} \mathrm{C}$ for 90 days). 
Table 10. Sensory properties of beef burgers as affected by substitution levels of WMRP and frozen storage period $\left(\right.$ at $\left.-18 \pm 2^{\circ} \mathrm{C}\right)$

\begin{tabular}{|c|c|c|c|c|c|}
\hline \multirow{3}{*}{$\begin{array}{l}\text { Storage period } \\
\text { (days) }\end{array}$} & \multicolumn{5}{|c|}{ Substitution levels of WMRP $(M \pm S E)$} \\
\hline & Control & $3 \%$ & $6 \%$ & $9 \%$ & $12 \%$ \\
\hline & \multicolumn{5}{|c|}{ Color } \\
\hline Zero time & $8.00 \pm 0.79^{b}$ & $8.00 \pm 0.81^{b}$ & $8.05 \pm 0.80^{b}$ & $8.20 \pm 0.81^{b}$ & $7.35 \pm 0.79^{b}$ \\
\hline 30 & $8.00 \pm 0.81^{\mathrm{b}}$ & $7.90 \pm 0.80^{\mathrm{b}}$ & $7.90 \pm 0.79^{\mathrm{b}}$ & $8.10 \pm 0.78^{b}$ & $7.30 \pm 0.81^{\mathrm{a}}$ \\
\hline 60 & $7.85 \pm 0.78^{\mathrm{b}}$ & $7.85 \pm 0.79^{\mathrm{b}}$ & $7.85 \pm 0.73^{\mathrm{b}}$ & $8.00 \pm 0.76^{\mathrm{b}}$ & $7.25 \pm 0.77^{\mathrm{a}}$ \\
\hline \multirow[t]{2}{*}{90} & $7.90 \pm 0.80^{\mathrm{b}}$ & $7.80 \pm 0.80^{\mathrm{b}}$ & $7.75 \pm 0.71^{\mathrm{b}}$ & $7.90 \pm 0.77^{\mathrm{b}}$ & $7.20 \pm 0.79^{\mathrm{a}}$ \\
\hline & \multicolumn{5}{|c|}{ Taste } \\
\hline Zero time & $8.05 \pm 0.70^{\mathrm{a}}$ & $8.00 \pm 0.70^{\mathrm{a}}$ & $8.05 \pm 0.70^{\mathrm{a}}$ & $8.25 \pm 0.72^{\mathrm{a}}$ & $7.30 \pm 0.69^{b}$ \\
\hline 30 & $7.80 \pm 0.72^{\mathrm{a}}$ & $7.90 \pm 0.71^{\mathrm{a}}$ & $7.95 \pm 0.72^{\mathrm{a}}$ & $8.00 \pm 0.71^{\mathrm{a}}$ & $7.10 \pm 0.77^{b}$ \\
\hline 60 & $7.90 \pm 0.77^{\mathrm{a}}$ & $7.80 \pm 0.72^{\mathrm{a}}$ & $7.85 \pm 0.70^{\mathrm{a}}$ & $7.90 \pm 0.70^{\mathrm{a}}$ & $6.90 \pm 0.74^{b}$ \\
\hline \multirow[t]{2}{*}{90} & $7.80 \pm 0.71^{\mathrm{a}}$ & $7.80 \pm 0.73^{\mathrm{a}}$ & $7.80 \pm 0.71^{\mathrm{a}}$ & $7.80 \pm 0.71^{\mathrm{a}}$ & $6.70 \pm 0.70^{\mathrm{b}}$ \\
\hline & \multicolumn{5}{|c|}{ Odor } \\
\hline Zero time & $8.10 \pm 0.70^{\mathrm{a}}$ & $8.10 \pm 0.71^{\mathrm{a}}$ & $8.15 \pm 0.71^{\mathrm{a}}$ & $8.20 \pm 0.70^{\mathrm{a}}$ & $6.80 \pm 0.70^{b}$ \\
\hline 30 & $8.000 .72^{\mathrm{a}}$ & $8.00 \pm 0.72^{\mathrm{a}}$ & $8.00 \pm 0.70^{\mathrm{a}}$ & $7.90 \pm 0.71^{\mathrm{a}}$ & $6.90 \pm 0.73^{b}$ \\
\hline 60 & $7.80 \pm 0.71^{\mathrm{a}}$ & $7.80 \pm 0.70^{\mathrm{a}}$ & $7.80 \pm 0.69^{\mathrm{a}}$ & $7.90 \pm 0.73^{\mathrm{a}}$ & $6.30 \pm 0.67^{b}$ \\
\hline \multirow[t]{2}{*}{90} & $7.60 \pm 0.70^{\mathrm{a}}$ & $7.60 \pm 0.71^{\mathrm{a}}$ & $7.70 \pm 0.72^{\mathrm{a}}$ & $7.75 \pm 0.72^{\mathrm{a}}$ & $6.30 \pm 0.70^{b}$ \\
\hline & \multicolumn{5}{|c|}{ Tenderness } \\
\hline Zero time & $7.90 \pm 0.80^{\mathrm{a}}$ & $7.90 \pm 0.76^{\mathrm{a}}$ & $8.00 \pm 0.70^{\mathrm{a}}$ & $8.05 \pm 0.70^{\mathrm{a}}$ & $7.45 \pm 0.66^{\mathrm{b}}$ \\
\hline 30 & $7.70 \pm 0.77^{\mathrm{a}}$ & $7.80 \pm 0.71^{\mathrm{a}}$ & $7.80 \pm 0.71^{\mathrm{a}}$ & $7.80 \pm 0.71^{\mathrm{a}}$ & $7.30 \pm 0.65^{\mathrm{b}}$ \\
\hline 60 & $7.80 \pm 0.71^{\mathrm{a}}$ & $7.60 \pm 0.77^{\mathrm{a}}$ & $7.65 \pm 0.72^{\mathrm{a}}$ & $7.90 \pm 0.72^{\mathrm{a}}$ & $7.20 \pm 0.67^{b}$ \\
\hline \multirow[t]{2}{*}{90} & $7.40 \pm 0.76^{\mathrm{a}}$ & $7.60 \pm 0.70^{\mathrm{a}}$ & $7.50 \pm 0.70^{\mathrm{a}}$ & $7.70 \pm 0.72^{\mathrm{a}}$ & $7.00 \pm 0.69^{b}$ \\
\hline & \multicolumn{5}{|c|}{ Juiciness } \\
\hline Zero time & $8.00 \pm 0.70^{\mathrm{a}}$ & $8.00 \pm 0.73^{\mathrm{a}}$ & $8.05 \pm 0.71^{\mathrm{a}}$ & $8.10 \pm 0.60^{\mathrm{a}}$ & $7.40 \pm 0.69^{b}$ \\
\hline 30 & $8.00 \pm 0.77^{\mathrm{a}}$ & $8.00 \pm 0.74^{\mathrm{a}}$ & $7.90 \pm 0.70^{\mathrm{a}}$ & $7.90 \pm 0.65^{\mathrm{a}}$ & $7.50 \pm 0.68^{b}$ \\
\hline 60 & $7.85 \pm 0.71^{\mathrm{a}}$ & $7.90 \pm 0.70^{\mathrm{a}}$ & $7.85 \pm 0.71^{\mathrm{a}}$ & $7.90 \pm 0.69^{\mathrm{a}}$ & $7.35 \pm 0.67^{b}$ \\
\hline \multirow[t]{2}{*}{90} & $7.65 \pm 0.69^{\mathrm{a}}$ & $7.70 \pm 0.71^{\mathrm{a}}$ & $7.70 \pm 0.70^{\mathrm{a}}$ & $7.80 \pm 0.61^{\mathrm{a}}$ & $7.15 \pm 0.66^{\mathrm{b}}$ \\
\hline & \multicolumn{5}{|c|}{ Appearance } \\
\hline Zero time & $8.00 \pm 0.70^{\mathrm{a}}$ & $8.05 \pm 0.71^{\mathrm{a}}$ & $8.10 \pm 0.70^{\mathrm{a}}$ & $8.20 \pm 0.71^{\mathrm{a}}$ & $7.50 \pm 0.66^{\mathrm{b}}$ \\
\hline 30 & $7.90 \pm 0.77^{\mathrm{a}}$ & $8.00 \pm 0.72^{\mathrm{a}}$ & $8.05 \pm 0.71^{\mathrm{a}}$ & $8.15 \pm 0.69^{a}$ & $7.55 \pm 0.67^{b}$ \\
\hline 60 & $7.80 \pm 0.68^{\mathrm{a}}$ & $7.80 \pm 0.71^{\mathrm{a}}$ & $7.90 \pm 0.73^{\mathrm{a}}$ & $8.00 \pm 0.70^{\mathrm{a}}$ & $7.30 \pm 0.68^{b}$ \\
\hline \multirow[t]{2}{*}{90} & $7.60 \pm 0.77^{\mathrm{a}}$ & $7.70 \pm 0.74^{\mathrm{a}}$ & $7.75 \pm 0.71^{\mathrm{a}}$ & $7.80 \pm 0.72^{\mathrm{a}}$ & $7.10 \pm 0.67^{b}$ \\
\hline & \multicolumn{5}{|c|}{ Overall acceptability } \\
\hline Zero time & $8.00 \pm 0.71^{\mathrm{a}}$ & $8.00 \pm 0.70^{\mathrm{a}}$ & $8.10 \pm 0.72^{\mathrm{a}}$ & $8.20 \pm 0.69^{\mathrm{a}}$ & $7.40 \pm 0.66^{\mathrm{b}}$ \\
\hline 30 & $7.90 \pm 0.70^{\mathrm{a}}$ & $7.90 \pm 0.71^{\mathrm{a}}$ & $8.05 \pm 0.71^{\mathrm{a}}$ & $8.10 \pm 0.70^{\mathrm{a}}$ & $7.10 \pm 0.67^{b}$ \\
\hline 60 & $7.70 \pm 0.73^{\mathrm{a}}$ & $7.70 \pm 0.71^{\mathrm{a}}$ & $7.80 \pm 0.73^{\mathrm{a}}$ & $7.95 \pm 0.71^{\mathrm{a}}$ & $7.20 \pm 0.70^{b}$ \\
\hline 90 & $7.60 \pm 0.71^{\mathrm{a}}$ & $7.70 \pm 0.73^{\mathrm{a}}$ & $7.75 \pm 0.70^{\mathrm{a}}$ & $7.80 \pm 0.70^{\mathrm{a}}$ & $7.00 \pm 0.68^{b}$ \\
\hline
\end{tabular}

$\mathrm{M} \pm \mathrm{SE}:$ Means \pm standard error; the means within the same row having different superscripts are significantly varied $(\mathrm{P} \leq 0.05)$.

\section{CONCLUSION}

Influence of substitution of texturized soy by different levels $(3,6,9$ and $12 \%)$ of watermelon rind powder from total formula of beef burger patties caused to improvement of gross chemical composition as that increased for crude fiber, total ash, total soluble carbohydrates content and decreased crude fat in beef burger patties, as well as the improvement of physiochemical quality criteria $(\mathrm{pH}$ value, WHC, shrinkage, TVN and TBA values) throughout frozen storage, in comparison with control sample. In addition, WMRP inhibited the growth and activity of microbial in tested prepared product. Also, beef burger patties containing the WMRP exhibited a good sensory properties and better acceptability, especially those contained 6 and 9 $\%$ of the WMRP, even after stored for 90 days under frozen condition. The present results are useful of used WMRP in fortification of meat products to improve the nutritionally and healthy safe.

\section{REFERENCES}

A.O.A.C. (2000): Official Methods of Analysis of the Association of Official Analytical Chemists $17^{\text {th }} \mathrm{Ed}$. Washington DC, USA.

Abd-Elghany, M.E. (2014). Effect of Quinoa seeds meal addition on the quality characteristics of beef Burger patties during frozen storage. J. Biolo. Chem. and Environ. Sci., 9(1):01-20.

Akgül, A. and Özcan, M. (1999). Some compositional characteristics of capers (Caper spp) seed and oil. Grasas Y Aceites, 50: 49-52.

Al-Sayed, H.M.A and Ahmed, A. R (2013). Utilization of watermelon rinds and sharlyn melon peels as a natural source of dietary fiber and antioxidants in cake. Ann. Agric. Sci., 58(1):83-95.

Apsara, M. and. Pushpalatha, P. B (2002). Quality degradation of jellies prepared using pectin extracted from fruit wastes. J. Tropical Agric., 40: 31-34. 
Bahorun, T., Luximon-Ramma, A., Crozier, A. and Aruoma, O.I. (2004). Total phenol, flavonoid, proanthocyanidin and vitamin $\mathrm{C}$ levels and antioxidant activities of Mauritian vegetables. J. Sci. Food Agric., 84: 1553-1561.

Brewer, M.S, Mckeith, F.K. and Britt, K. (1992). Fat, Soy and Carrageenan Effects on Sensory and Physical Characteristics of Ground Beef Patties. J. Food Sci., 57 (5): 1051-1052

Bryan N. S. (2016). Dietary Nitrite: from menace to marvel. Functional Foods in Health and Disease; 6(11): 691-701.

Cosmos, E. and Simon-Sarkadi, L. (2002). Characterization of tokay wines based on free amino acid and biogenic amine using ion-exchange chromatography. Chromatographic supplement, 56:185-188.

Cross, H.R., Moen, R. and Stanfield, M.S. (1978): Training and testing judges for sensory analysis of meat quality. Food Techno., 36: 48- 52, 54.

Downes, F.P., Ito, K. (Eds.), (2001). Compendium of Methods for the Microbiological Examination of Foods, forth ed. APHA, Washington, DC.

Dreeling, N., Allen, P. and Butler, F. (2000). Effect of the degree of comminution on sensory and texture attributes of low-fat beef burger. Lebensm-WissuTech.,33:290-294.

El-Badry, N., El-Waseif, M.A., Badr, S.A. and Ali H.E. (2014). Effect of Addition Watermelon Rind Powder on the Rheological, Physiochemical and Sensory Quality Attributes of Pan Bread. Middle East J. Middle East J. Applied Sci., 4(4): 10511064.

EOS. (2005). Egyptian Organization for Standardization and Quality Control for Frozen beef burger No. 1688.

FAO/WHO. (1973). Energy and Protein Requirements. Report of a Joint FAO/WHO Ad Hoc Expert Committee.WHO Tech. Report Series 522, FAO Nutrition Meetings Report Series, 52, Rome, Italy.

FDA, (2005). Bacteriological Analytical Manual, 18th ed. AOAC, Washington, DC.

Gomez, K.A. and Gomez, A.A. (1984). Statistical Procedures for Agricultural Research $2^{\text {nd }}$ Edn. John Wiley, New York, USA.

Hatano, T., Kagawa, H. Okuda, T. and Yasuhara, T. (1988). Antioxidant Activity and volatile components of Egyptian Artemisia judaica L. Chem. Phar. Bull, 36:2090-2097.

Hill, M.J., Massey, R.C., Shuker, D.E., Leach, G.S., Tricker, A.R. Preussmann, R. and Rowland, J.R. (1988). Nitrosamines. Toxico. and micro. 169pp. Ellis Horwood Ltd., UK. ISBN 0-89573-605-0.

Keum, Y.S., Jeong, W.S. and Kong, A.N.T. (2004). Review: Chemoprevention by isothiocyanates and their underlying molecular signaling mechanisms. Mutation Research, 555: 191-202.

Kim, B.H., Lee, H.S., Jang, Y.A., Lee, J.Y., Cho, Y.J. and Kim, C. (2009). Development of amino acid composition database for Korean foods. J. Food Composition and Analysis 22: 44-52.
Li, L., Shao, J., Zhu, X., Zhou, G. and Xu, X. (2013). Effect of plant polyphenols and ascorbic acid on lipid oxidation, residual nitrite and n-nitrosamines formation in dry-cured sausage. International $\mathrm{J}$. Food Sci. and Tech., 48(6): 1157-1164.

Lin, C.M., Preston, J.F. and Wei, C.I. (2000). Antibacterial mechanism of allyl isothoicyanates. J. Food protection, 63 (6): $727-734$.

Mukhopadhyay, S. and Bhattacharyya, D.K. (2006). Colorimetric estimation of allyl isothyocianate content in mustard and rapeseed oil. Wiley. International Sci., 85(8):309-311.

Murray, P.R., Baron, E.J., Jorgensen, J.H., Landry, M.L., Pfaller, M.A., (2007). Manual of Clinical Microbiology, ninth ed. American Society for Microbiology, Washington, DC.

Oroszvári, B.k., Rocha, C.S., Sjöholm, I. and Tornberg, E. (2006). Permeability and mass transfer as a function of the cooking temperature during the frying of beef burgers. J. Food Engineering, 74; 1 12.

Oroszvári, B.k., Bayod, E., Sjohölm, I. and Tornberg, E. (2005). The mechanisms controlling heat and mass transfer on frying beef burgers. 2. The influence of the pan temperature and patty diameter. J. of Food Engineering, 71: 18-27.

Osheba, A.S., Hussein, S. and El-Dashlouty, A.A. (2013). Evaluation of some vegetal colloids on the quality attributes of beef sausage. Advance Journal of Food Science and Technology 5 (6): 743-751

Ou, D. and Mittal, G.S. (2006). Double-sided pan-frying of unfrozen/frozen hamburgers for microbial safety using modelling and simulation. Food Research International, 39 (3): 133-144.

Özkan, N., Ho, I. and Farid, M. (2004). Combined ohmic and plate heating of hamburger patties: quality of cooked patties. J. Food Engin., 63: 141-145.

Passos-Maria, H.C.R. and Kuaye, A.Y. (2002). Influence of the formulation, cooking time and final internal temperature of beef hamburgers on the destruction of listeria monocytogenes. Food Control, 13: 33-40.

Paul, A. A. and Southgate, D. A. (1979). The composition of foods. $4^{\text {th }}$ edn. Elsevier /North. Holland Biomedical Press, Amsterdam.

Pearson, S. (1976). Chemical analysis of food. 8th Ed. Harold Egan, Ronald S. Kirk Roland Saweyer (London).

Perkins-Veazie, P., Collins, J.K. and Clevidence, B. (2007). Watermelons and health.ActaHorticulturae (ISHS)731: 121-128.

RDA., (1989). Recommended Dietary Allowances of Minerals, Subcommittee on the 10th Edition of the RDAs Food and Nutrition Board Commission on Life Sci. Natio. Rese. Council, Natio. Academy Press, Washington, D.C.

Rhee, M.S., Lee, S.Y., Dougherty, R.H. and Kang, D.H. (2003). Antimicrobial effects of mustard flour and acetic against Escherichia coli 0157: H7, Listeria monocytogenes and Sallmonella enterica Servar typhimurium. Applied and Envir. Micro., (5): 2959 2963. 
Rimando, A.M. and Perkins-veazie, P. (2005). Determination of citrulline in watermelon rind. J. Chrom., 1078: 196-200.

Schoeni, J. L., Brunner, K. and Doylle, M.P. (1991). Rates of thermal inactivation of Listeria monocytogenes in beef and fermented beaker sausage. J. Food Protection, 54: 334 -337.

Singleton, V.L., Orthofer, R. and Lamuela-Raventos, R.M. (1999). Analysis of total phenols and other oxidation substrates and antioxidants by means of Folin-Ciocalteu reagent. Oxidants and Antioxidants. 299: 152-178.

Skibsted, L. H. (2011). Nitric oxide and quality and safety of muscle based foods. Nitric oxide, 24(4): 176183.

Soloviev, A.A. (1966). Meat aging In "Food Industry" Pub. (Moscow) 53-81, 82-164, 242 -303.

Stahnke, L.H. (1995). Dried sausage fermented with Staphylococcus xylosus at different ingredient levels Part I. Chemical and bacteriological data. Meat Sci., 41(2): 179-191.
Tlili, I., Hdider, C., Lenucci, M.S., Riadh, I., Jebari, H. and Dalessandro, G. (2011). Bioactive compounds and antioxidant activities of different watermelon (Citrullus lanatus (Thunb.) Mansfeld) cultivars as affected by fruit sampling area. J. Food Compos. Anal., 24(3):307-314.

USDA, (2004). US Department of Agriculture, Agricultural Research Service, USDA National Nutrient Database for Standard Reference, Release 17, Nutrient Data Laboratory Home Page, http:// www. nal. Usda .gov/fnic /foodcomp.

Wehr, H.M. and Frank, J.H., (2004). Standard Method for the Microbiological Examination of Dairy Products, 17th ed. APHA Inc., Washington, D.C.

Zhang, Y., Liu, J. and Tang, L. (2005). Cancer-preventive isothoicyanates: dichotomous modulators of oxidative stress. Free Radical Biol. and Medi., 38:70-77.

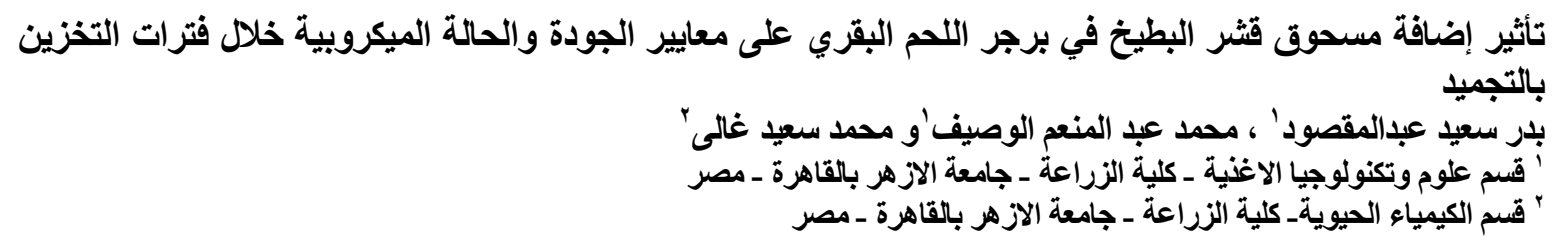

يعتبر مسحوق قشرة البطيخ مصدر طبيعي للألياف الغذائية والمعادن و الأحماض الأمينية والمركبات المضادة للأكسدة الطبيعية. وقد نم

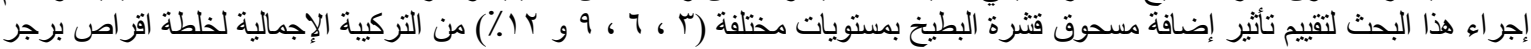

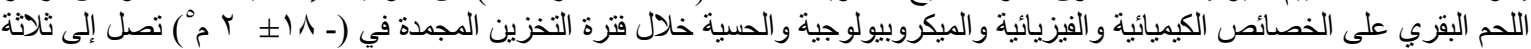

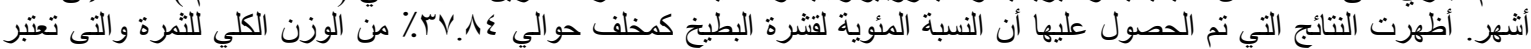

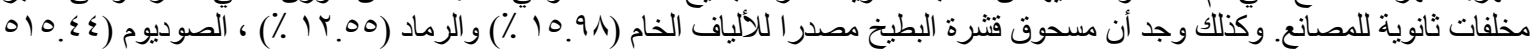

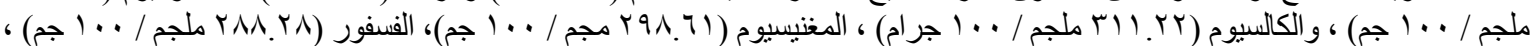

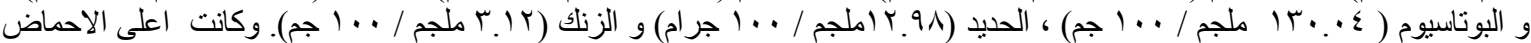

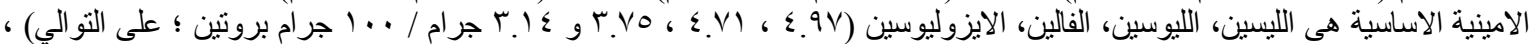

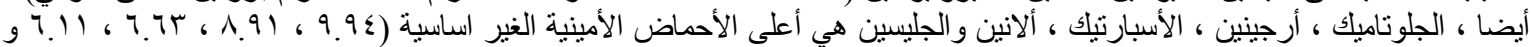

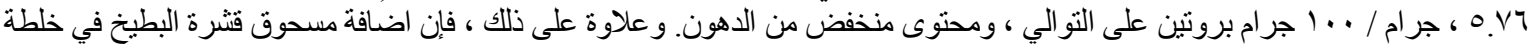

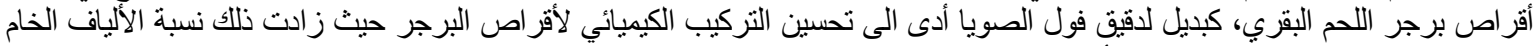

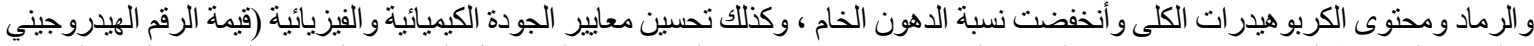

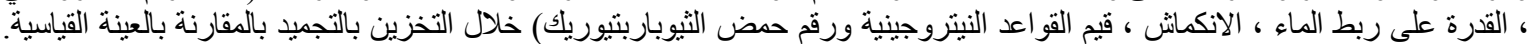

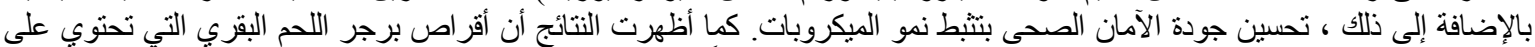

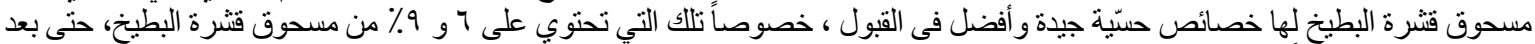

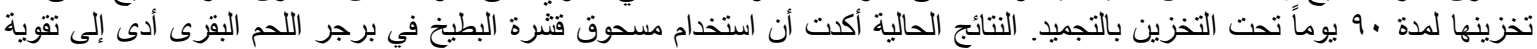
وتدعيمه منتجات وتحسين السلامة و والآمان من الناحية التغذوية ولنية الصحية. 